\title{
Importance of Development Initiative Ownership by the Benefiting Community: The case of Community-Based Production and Marketing Systems
}

\author{
Kavoi J*, G Kamau and R Kisilu \\ Senior Research Officer, Kenya Agricultural \& Livestock Research Organization, Kenya \\ Submission: June 06, 2018; Published: October 09, 2018 \\ "Corresponding author: Kavoi J, Senior Research Officer, Kenya Agricultural \& Livestock Research Organization, KALRO-Katumani Research \\ Centre, Kenya, Tel: +254733573387; +254726250090; Email: j.kavoi59@gmail.com
}

\begin{abstract}
This case study used a Private Public Partnership on a Gadam sorghum development initiative with a view to understanding the conceptualization, implementation, outputs, outcomes and lessons for policy, practice and research. The development initiative involved several stakeholders, namely, East African Breweries, Researchers, Ministry of Agriculture, Equity bank, Smart Logistics and Provincial administration, Ministry of culture and Social Services, and farmer producer groups. Research and development agencies introduced several organizational and technical innovations including production clusters, improved sorghum, payment using warehouse receipts and others. The farmers brought in various technical innovations, which included bird diversion strategies, bird avoidance strategy, planting along plough furrows and many sorghum recipes. The diverse recipes led to a change of perception towards this high value traditional crop and thus the grain became a source of food for the farmers. Payment through the bank helped the farmers to access finances easily and other banks started similar initiatives in the area. It was observed that a technology without appropriate configuration of partners will not create the desired impact. Communication between partners is important towards sustaining the innovation process and a feedback capture and incorporation tool into research is necessary. It was also apparent that support to the whole value chain is important rather than focusing on the output end of the chain. There is therefore need for policies to balance between the profit needs of the entrepreneur and the income/food needs of the farmers. It is important for producers to own such initiatives in order to build sustainability of the innovation process beyond the expiry of external agency intervention initiatives. There is also need to encourage formation of structures representing farmers to negotiate fair contracts with partners or to provide technical advice or credit to their members.
\end{abstract}

Keywords: Gadam sorghum; Perception; Recipes; Communication; Sustainability

Abbreviations: ASALs: Arid and Semi-Arid Lands; KASAL: Kenya Arid and Semi-Arid Lands; MoA: Ministry of Agriculture; NGOs: NonGovernmental Organizations; EABL: East Africa Breweries Limited; CCA: Collaborative Case Assessment and DAO: District Agricultural Office

\section{Background}

The genesis of this initiative was a grain consumption study conducted in 2008, which showed that 100 million Kgs of barley were being used annually by the Kenya Breweries for beer brewing. Most of this barley was imported due to the low quantities of locally produced barley. One of the reasons for low local barley production was the government's directive to discourage barley farming in the Mau forest water catchment area which accounted for most of the barley produced locally. Owing to the high foreign exchange expenditure on imported barley, an effort was made to look for an alternative crop to replace barley. Gadam sorghum was found to be suitable due to its high quantity of fermentable starch. The challenge was how to produce the required quantities since farmers in the traditional sorghum growing Arid and Semi-Arid Lands (ASALs) have more preference for maize and hence put most of their land under maize. This occurs despite the poor performance of the maize crop. A solution to solve this challenge was found in the form of an initiative to grow Gadam sorghum under the auspices of the Kenya Arid and Semi-Arid Lands project.

The Gadam sorghum initiative was a Public Private Partnership and was implemented in Kitui, Machakos and Makueni Counties of Eastern Kenya. The aim of the initiative was to organize production and marketing of Gadam sorghum. The partners involved were Kenya Arid and Semi-Arid Lands (KASAL) project, the Ministry of Agriculture (MoA), the Provincial administration, Non-governmental organizations (NGOs), East Africa Breweries limited (EABL) and Banks. The activities undertaken by different partners in the initiative involved farmer mobilization and sensitization, awareness creation on appropriate agronomic practices, formation of production cells, collection and delivery of Gadam grain, issue of a warehouse receipt and payments through commercial Banks. In Kitui County, the initiative was 
started in Migwani and this was the focus of this collaborative case assessment. Later the initiative spread to other districts and requests of seeds and information about the model have been received from as far away as Uganda [1-3].

\section{Objectives of the Gadam JOLISAA Collaborative Case Assessment}

The major objective of the Gadam sorghum collaborative case assessment was to assess and understand the past and current Gadam innovation process(es) through:

a. Establishing the innovation background,

b. Determination of the status of sorghum commercialization PPP initiative,

c. Highlighting any new directions and developments in the initiative including emerging issues, constraints and successes,

d. Documentation of the lessons learnt for research, policy and practice.

\section{Specific Issues Addressed in the Collaborative Case Assessment}

This collaborative case assessment (CCA) was aimed at understanding the conceptualization, implementation, outputs, outcomes and lessons for policy, practice and research of the Gadam Sorghum PPP case. During the assessment period, a checklist for data collection which contained the following questions was used.

\section{What were the reasons behind the establishment of the gadam sorghum PPP, how did it start and who was involved?}

This question was meant to establish how and why the innovation started, who the drivers (stakeholders) were and which roles they played. Additionally, it also sought to know the active stakeholders, those who dropped and those who have joined as stakeholders during the innovation process and what attracted them. The relationships among the players e.g. conflicts and partnerships' and their evolvement were also looked into.

\section{What happened from production to marketing?}

This was meant to find out what production to marketing entails in terms of the kind of activities undertaken, how involving and or challenging they are and who conducts these activities. This question also sought to bring out the different sorghum products because of the innovation, their marketing, demand and supply, value addition innovations and the challenges met by those involved.

\section{What is the geographical spread of the innovation?}

This was to determine the scalability of the innovation geographically, group wise and the number of people involved. It was also to determine the reasons for the spread (if any) as well as any obstacles to the spread.

\section{What were the new knowledge and skills brought in to modify/ improve the innovation?}

This question highlighted any knowledge and skills and the influence of those skills to the innovation process. It was important to bring out the different knowledge and skills contributing to the innovation process and the stakeholders who introduced them. Special emphasis was put into the farmers' knowledge and skills and how they were mobilized.

\section{What were the agricultural research and development contribution in the innovation process?}

This question sought to find out the roles played by Agricultural Research and Development (ARD) stakeholders and the reaction from the other stakeholders towards them [4-6].

\section{Methodology}

The CCA was conducted in several locations in Nguutani Division, Migwani district and started with a review of background information on the Gadam sorghum initiative to understand how it started and how it progressed. Any available reports were accessed, and the contents were analyzed. Visits were thereafter made to the District Agricultural Office (DAO) Migwani, during which the target locations and villages were mapped out and individuals, farmer groups and other stakeholders were identified Field data were collected using a checklist (see appendix) through a semi structured interview (SSI), General group discussions (GGDs), Focused Group Discussions (FGDs), Individual farmer interviews, Key Informant interviews; direct observations and key stakeholder interviews. The FGDs comprised of 8-10 group members selected during the general group discussions and were used for following up on issues emerging from the GGDs and Key Informant Interviews. Key informants included the District extension staff Migwani, Smart logistics, local traders, Equity Bank and EABL. Respondents for the Individual farmers and key informant's interviews were randomly selected during the general group discussions from among the group members who did not attend the group meetings. The individual farmer interviews also involved farmers who were not members of any group but were growing and selling Gadam through the groups and therefore could easily be identified. Farmer groups included those that were initially involved in the innovation process and others who learnt from the original groups.

During this CCA, 7 general group discussions, 3 FGDs, 15 individual farmers, 3 key informants, 5 key stakeholders (P.I, DAO Migwani, EABL, Smart logistics and Equity bank) and 3 local traders were interviewed. At the end of the CCA, a multistakeholder workshop was organized to concretize/validate the findings. A total of 23 farmers/farmer group and organizations representatives, 5 scientists from KARI Katumani and two from KARI Headquarters, 2 officers from the Ministry of Agriculture extension, 4 local leaders/provincial administration, EABL, 2 local traders and Smart logistics were invited. In summary, the CCA team worked on the logistics that would enable the CCA exercise to run smoothly [7]. 


\section{Results and Discussions}

\section{Identification of sorghum variety suitable for brewing}

Analysis of barley, maize and sorghum samples for carbohydrates by East African breweries revealed $75 \%$ carbohydrate in sorghum compared to $67 \%$ in barley and $66 \%$ in maize, making sorghum a good alternative source of fermentable sugars. Further analysis involving several improved sorghum varieties found sorghum had very low levels of oil and proteins, which makes it good for industrial processing. Gadam sorghum was preferred for its earliness in maturity hence well adapted to the low rainfall conditions of the ASALs.

\section{Identification and bringing together of the stakehold- ers}

Several initiatives to commercialize agriculture by various organizations have been initiated with various results. Although, Kenyan farmers respond positively to market-driven enterprises in ASALs, the problems they experienced in these initiatives such as failure of buyers to come for produce as promised, breaking of contracts etc left them sceptical and with eroded confidence to similar approaches. The farmers needed to have confidence that they can use their resources to plant Gadam and market it for income. KARI-Katumani through the Kenya Arid and Semi-Arid Lands (KASAL) project undertook to the commercialization of Gadam sorghum initiative in order to bridge the gaps between the potential investor (market) and producers (farmers) of Gadam (the raw material). It involved getting various stakeholders to assist farmers in organizing themselves into production and marketing structures for marketing acceptable high-quality sorghum grain. The joint initiative took a PPP orientation, that brought together the Kenya Agricultural Research Institute (KARI), the Ministry of Agriculture (MoA), the Provincial administration, Non-governmental organizations (NGOs), EAML and the East Africa Breweries limited (EABL) and Banks on the importance of growing sorghum as a cash crop in lower semiarid Eastern Kenya.

\section{Formation of farmers' sorghum production cells}

The Initial undertakings were carried out in 2008 but prolonged drought made all the efforts futile. The work was rekindled during 2009/2010 short rainy season. Sensitization and stakeholders' training workshops were held in different districts in lower semi-arid Eastern Kenya. With the assistance of local public extension staff, best bet sorghum production sites were identified and selected for piloting promotion of Gadam production of which Nguutani in Migwani district was one. Production cells were then formed from already established farmer groups of between 15 and 30 interested members for ease of training, follow up and produce aggregation. A total of 136 production cells with about 3,000 farmers spread across participating districts in semi-arid lower Eastern Province and upper coast were formed. This was to ensure collective production, control of bird damage and increased productivity. According to a respondent in another group, 'We were promised a ready market for the sorghum and hence we planted and took care of the [8].

\section{Provision of proper planting material and training on proper agronomic and marketing practices}

KARI-Katumani distributed Certified Gadam sorghum seeds before the onset of 2009 short rainy for timely planting. Training of stakeholders/partners on the agronomy, use of fertilizer/ farmyard manure, mono cropping, grain aggregation and quality maintenance/ control was carried out. At the time of the postseason review meeting, 500 metric tonnes of quality sorghum grain had been delivered to the EAML depot, Nairobi. This translated to slightly above eight million Kenya Shillings paid to farmers in season one. Past studies in the sorghum growing areas showed that women do most of the farming activities (Kavoi, 2003), while men engage in off-farm income generating activities. With the introduction of Gadam sorghum as a cash crop, the number of men growing the crop almost equalled that of women, with the productivity increasing in the progressive years.

\section{Collective marketing, warehouse receipting and con- tract signing}

Gadam farmers were given an opportunity to sign a contract with the agents or buyers before supplying their produce. This was aimed at protecting both the farmer and the agent. For ease of product marketing, produce aggregation points for the specific production cells were introduced by the buyers. After harvesting, farmers collected the grain in one central place for the buyer to collect and issue a warehouse receipt for later payment through a commercial bank.

\section{Payment through the bank}

This was introduced for security purposes and also to facilitate access to credit facilities. Farmers were required to open bank accounts to receive payments through the bank on production of a warehouse receipt issued by Smart Logistics.

\section{Plough planting}

To reduce the costs of Gadam sorghum production, farmers ploughed their land using a modified plough (removed mouldboard) which is ox drawn. The ploughing combined ploughing and planting in one operation by placing the seed in the plough furrow and covering as the ploughing continued. This ploughing had to be shallowly done to ensure that the seeds were shallowly covered. Soon as germination was observed, ox weeding would be done with someone following behind the plough to straighten the seedlings pushed by the ploughed soils.

\section{Intercropping}

Although farmers were advised to plant sorghum as pure stands and use their fertile farm portions, many farmers intercropped Gadam sorghum with pulses. This was to avoid replacing the pulses with sorghum. As per comments by one farmer, "we were advised not to intercrop sorghum with pulses. 
However, on my farm I have been intercropping but using wider spacing than the one recommended by the extension staff and that way I get two crops rather than one". The issue of yield increase advantage was however not well agreed upon since some farmers said that you got less yields when sorghum is intercropped while others claimed that there were higher yields.

\section{Threshing and winnowing}

Farmers observed that when they thresh sorghum early in the morning (8:00-10:00 a.m.) or late in the evening (5.00 -7.00 ) the grains come out of the awn without the bract and thus it is easier to winnow and clean than during the hot and dry part of the day. They have also observed that Gadam sorghum does not cause as much itching as the other varieties when threshing. Thus, according to one respondent 'we thresh late in the evening or early in the morning to avoid 'kunyeewa' (local word for itching'. From the interactions during interviews and the workshop, it is apparent that the original PPP model was not being followed fully. The ready market and the crop resilience to drought have, however, enabled the progress of the activity even though on a small scale and low pace. The only players who are still interacting with the farmers are those involved in marketing, the extension and those supplying seeds. The interactions have however not always been very cordial. Actors who relied on donor funds (project funds) for their activities no longer visit or interact with the farmers.

Information available also indicates that only those individuals and groups who had contact with the project initiators had the full information about the initiative and the model. The other actors and players appear to have concentrated on their entry point in the chain. The biggest concentration has been in the marketing segment and seed supply where the driving force has been profit or rewards from the chain and this is what is disrupting the chain. Disparities in sharing of proceeds, pricing and variability in production have constrained value chain enhancement. Industrial investors need to be sure of adequate and sustained supply of raw material to invest in a potential market. The brewers must be assured of adequate and sustained supply of good quality Gadam sorghum to meet their yearly demand and all the stakeholders need assurance of success. Kenya breweries required an initial supply of 24,000 tons of white grain sorghum annually opening a large frontier for the Gadam sorghum. This quantity was not available from lower Eastern Kenya and hence they had to move to areas where there was assured production. The arrangement they put in place in the lower Eastern in form of additional agents was not made clear to the producers.

The main agent of the breweries, Smart logistics did not create awareness to the producers about the changed position and hence this created a discord between the major players. This may be attributed to the lack of an information broker who could have traversed the two actors to explain the respective positions. This led to frustrations on the part of the producers. Another source of frustration was after the delivery of produce followed by a prolonged lapse in payment. This was not explained to the producers and this became a source of discontent to them. This position was only explained during the stakeholder meeting when the breweries agent explained the lapse in payment to the main agent owing to a delayed delivery. In the new regions of upper Eastern, Rift Valley and the Western region, the PP model seems to be working well which may be attributed to the scale of operation and the high potential in these new areas. It is also worth of note that what initially started off as a commercial activity slowly turned into a food security activity. The farmers have converted the sorghum grain into food and there is an opportunity to expand on this by for example reducing the drudgery in the processing and production. The experiences in this part of the country helps to illustrate that if properly handled, sorghum can form part of the strategic food reserves in the countries grain reserves. A step towards this would be blending of sorghum with maize or cassava and a policy message in this direction could perhaps speed up the process.

Owing to the lucrative innovation process, other seed suppliers have taken advantage and brought in seeds that are not of good quality. The farmers have no way of knowing the true quality of seeds and in any case some of these actors provide the seeds free of charge. It is only once they are in the field that farmers realize the poor-quality performance. Stakeholders in such situations could come up with simple ways to authenticate the seed sources similar to some seed companies that have come up with mobile phone service that helps farmers to know whether seed is genuine or fake. It is also apparent that by and large, the biggest hindrance to the progress of this process is drudgery at various levels. Mechanisms to remove the drudgery could be useful towards encouraging production and marketing the sorghum. Refinement of the bird scaring innovations could be a boost towards production of the crop $[9,10]$.

\section{Lessons for Research, Policy and Practice}

From the Gadam CCA, there are lessons to draw relating to research, policy and practice.

\section{Lessons Learnt for Research}

\section{a. Enabling environment for technology scaling and} impact

A technology without an enabling environment will not lead to the expected impact. Appropriate configuration of partners in an innovation platform for exchange of information and stimulation of innovation is necessary. The model applied in this case that brought together different partners is what led to the success that was realized. Other value chains could also benefit from the same approach and research policies ought to encourage this.

\section{b. Framework for feedback capture and incorporation} into research

Observations and discussions in the course of the assessment indicated that there were several gaps in the information 
available with the producers. This related to production practices which are either addressed by recommendations from research or not addressed at all. Farmers made adjustments to the recommended practices and came up with own practices and in case of absence of recommendations, they developed their own practices which were informed by what they have always done as well as modifications of what is recommended for other value chains. Strategies to capture such feedback are critical to help in refining production practices that emanate from research and development partners. Examples are sorghum intercropping, bird diversionary crops and water harvesting practices among others.

\section{c. Water harvesting practices}

Various water harvesting methodologies have been recommended for the ASALs by research and their results have been found satisfactory. These methods require various equipments that may be inaccessible to small holder farmers. The farmers use ox- ploughs and the implements used are inadequate for the water harvesting requirements since these are meant for land preparation and weeding. The opening of furrows at weeding time is insufficient to hold rain water and retain it for infiltration into the soil. There is therefore need to do research that would make the operation more efficient and at the same time less laborious. Efficient and less labour intensive water harvesting methods/equipment especially those that could be combined with oxen plough practices should be explored.

\section{Lessons for policy}

a. Sorghum as a strategic food reserve (Blending with maize and other flours)

Observations in the Gadam case have shown that sorghum has become a source of food even though the intention was income from sale to the breweries. By consuming sorghum, there is less pressure on the staple crop-maize which is most of the times in short supply. One way of further reducing the pressure is to formulate policies that would encourage sorghum and other such cereals to be targeted as strategic food reserves. The policy may also target blending of sorghum with other cereal flours.

\section{b. Collective Production and Marketing}

A major challenge that confronts producers is production of crops in isolated fields which in turn makes acquisition of necessary inputs difficult. It also makes the fields vulnerable to damage by pests and vermin such as birds. The 'production clusters model' and the aggregation for marketing led to the success that was recorded and it would be useful to encourage and nurture this approach through formulation of enabling policies. This has worked well also for other crops like tea and coffee and could be extended to food crops. The aggregation has also been used successfully by middlemen who aggregate produce for collection in one site and transport in bulk making use of economies of scale.

\section{c. Support to total value chain}

There is need to advocate for support to the whole value chain rather than focusing on the output end of the chain. The input end only involved seeds and the backstopping whereas other inputs such as labour for planting, weeding and harvesting were not considered. It would be appropriate for an investor to put in the required input to support the entire chain. Modalities can be worked out to ensure that the arrangement is not used to exploit the farmers like has happened in the past and there is need for a policy to support this.

\section{d. Balance between profit and farmer income/food needs}

There is need for policies to balance between the profit needs of the entrepreneur and the income/food needs of the farmers. Such a policy would also guide and support other PPP initiatives which are currently picking momentum.

\section{Lessons for practice}

It is important for producers to own initiatives such as these ones started off by private and public entities right from inception. Unless ownership is internalized by producers, the dynamics will slow down on the expiry of the period that the activity is in the process.

\section{a. Water harvesting key to improved production}

Given the scarcity of moisture in the ASALs, it is necessary to encourage water harvesting practices in the production of crops such as sorghum. The producers ought to be aware of this requirement and incorporate it in their husbandry practices.

\section{b. Change of perception}

Gadam sorghum that was initially considered for commercial use has become a source of food and therefore offloads pressure from maize. There is need to change perception/attitude towards high value traditional crops like sorghum and others (diverse dishes/recipes) at farm level.

\section{c. Production clusters}

Producers may need to reorganize themselves into production clusters to minimize losses due to pests as well as facilitation of easy access to inputs. This also applies to collective marketing of produce as shown by the Gadam platform model.

\section{Conclusion and Recommendations}

This innovation process seems to point out that there are several issues that ought to be addressed before realizing a fully operational PPP process. The period of operation needs to be taken into consideration so that enough time may be allowed to explore all angles. What is more critical is for arrangements in these partnerships to cater for the long-term sustenance of what is initiated to avoid experiences that discourage the farmers. This becomes worse when the farmers taking part in the PPP are individuals. 
Based on the CCA study findings, there is need to identify measures to undertake so as to address the low Gadam sorghum production in the region, high cost of production and credit accessibility by smallholder farmers. There is also need for development of strategies to address the socio-cultural perception of sorghum and other traditional crops in the entire country. This would provide an enabling environment for actualization of a policy instrument that would support increased use of sorghum including its use as a strategic grain item. A policy advocacy campaign would lead to sorghum inclusion in the strategic food reserve and the blending with maize and other cereals.

Sensitization of farmers from time to time on the facilities available in agricultural sector that would assist them is necessary to increase Gadam sorghum production and marketing in the region. For instance, financial institutions such as Equity bank have set credit under the facility Kilimo Biashara. Surprisingly, none of the farmers interviewed are going for it to increase Gadam production. Although, the current interest rate for this credit facility is $12 \%$ as compared to the $24 \%$ interest rate for other loan facilities, only traders are taking advantage of the same. For the credit facility to be of utility to the farmers there is need to link the facility with, for example, provisions for water harvesting or conservation practices to ensure successful operation of choice by the farmers.

Many of the organizations supporting farmers are only engaged in training and seed provision. There is need for some to be organized to address other issues in the Gadam value chain such as land preparation, fertilizer application and planting machines and farmers encouraged to plant at least half an acre of Gadam. The strategies in place to promote Gadam production are not adequate. Seed production and certification structures similar to the ones used by the KARI seed unit ought to be established to ensure quality seeds are availed to farmers. There is need to enhance the commercialization initiative by spreading the innovation to larger number of farmers. There is also need to develop an organization at farmer level that that will enable farmers to interact more closely and share ideas. Such structures are the same ones that will ensure sustainability of the initiatives long after the official period of initiatives such as the Gadam PPP.
With regard to marketing, there is need to have agents and subagents to enhance the grain marketing since not many traders would raise the desired capital to run the process sufficiently [11-12].

\section{References}

1. Food and Agriculture Organization (2007). Food security status in 23 districts of Kenya, Kenya.

2. Kaloi E, Tayebwa B, Bashaasha B (1994) Food security status of households in Mwingi District. African Crop Sci. Conference, Kenya, Proc 7: 867-873.

3. Karanja DR, Kamau CK, Ariithi CK, Kisilu R, Kavoi J, et al. (2011) Improving food security and incomes for farmers in semi-arid $\mathrm{l}$ areas through commercialization of sorghum Gaddam Production and marketing mode with small-scale farmers.

4. Agricultural Research Institute Annual report, Kenya (2009).

5. Kavoi J, Karanja D, Mulwa D, Mugo N (2003) A Training Manual for Enhancing Food Security in Semi-Arid Eastern Kenya through Promotion and Uptake of crop protection Research output. Produced with facilitation of Natural Resources Institute and DFID KARI Katumani, Ministry of Agriculture and Catholic Diocese of Kitui, UK, London.

6. Kavoi J, Karanja D, Wafula J (2010) Turning Challenges into Opportunities: Commercialization of Gadam Sorghum in Maize Dominated Farming Systems of Lower Semi-Arid Eastern Kenya. $12^{\text {th }}$ KARI Biennial scientific conference, Kenya.

7. Lawes RA, Wegener MK, Basford KE, Lawn RL (2004) The evaluation of the temporal and spatial stability of sugarcane farm performance based on yield and commercial cane sugar. Australian Journal of Agricultural Research 55(3): 335-344.

8. Ragwa M, Bugusu LB, Mburu C, Wanjohi M, Hudgens R, et al. (1997) Sorghum and Millet Production and Utilization Guidelines, Nairobi, KARI Headquarters, Kenya.

9. NEMA Mwingi District Environmental Action plan (2009).

10. Triomphe B, Crane T, Almekinders C, Harms B, Fagbemissi R (2010) Guidelines for the inventory of innovation cases. JOLISAA internal project document, Montpellier, 31, France.

11. Triomphe B, van den Berg J, Kamau G, Floquet A, Letty B, et al. (2012) JOLISAA approach and guidelines to collaborative case assessment. JOLISAA internal project document. Montpellier, 46, France.

12. World Bank Enhancing agricultural innovation: how to go beyond the strengthening of research systems (2006). Washington, World Bank, 157, USA.

\section{This work is licensed under Creative}

Commons Attribution 4.0 License

\section{Your next submission with Juniper Publishers} will reach you the below assets

- Quality Editorial service

- Swift Peer Review

- Reprints availability

- E-prints Service

- Manuscript Podcast for convenient understanding

- Global attainment for your research

- Manuscript accessibility in different formats

( Pdf, E-pub, Full Text, Audio)

- Unceasing customer service

Track the below URL for one-step submission https://juniperpublishers.com/online-submission.php 